\title{
Articles
}

\section{Study on the policy-relevance of existing crime data}

\author{
Ana Isabel Pérez Cepeda, Demelsa Benito Sánchez, María Concepción \\ Gorjón Barranco *
}

At present, there is a lack of high-quality comparative data on crime trends. This fact inevitably hampers the adoption of evidence-based policies. Several initiatives have already been launched by the European Union in the past years, underlying the necessity of gathering reliable data on crime in addition to using such data for developing European criminal policy. The purpose of this paper is first, to envisage a study of the initiatives that have already been undertaken. Next, a brief description of the decision-making process in criminal matters at the European level will be provided, with the aim of determining the point in the entire process at which crime data should be used by policymakers and whether the available crime data are currently being integrated into the development of criminal policy. Finally, since the results of our research showed that European policymakers make little use of the existing data, the paper will analyse the main reasons for such limited use and provide some proposals to improve the degree of policy relevance of the data.

\section{Introduction}

The purpose of this paper is to identify the main reasons why the existing data on crime trends have limited influence on the decision-making process at the European level, and to suggest some recommendations for improvement.

In recent years, we have repeatedly heard calls on national and international levels for "evidence-based policy", or, in other words for "the application of scientific experience and scientific methods of decision-making in each phase of the political

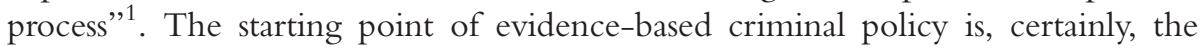
existence of reliable data. However, at present we lack high-quality comparative data on crime trends at the European level, notwithstanding the fact that several organisations collect data in this field ${ }^{2}$.

\footnotetext{
* Professor Dr. Ana Isabel Pérez Cepeda (University of Salamanca), Dr. Demelsa Benito Sánchez (University of Salamanca), Dr. María Concepción Gorjón Barranco (University of Salamanca). This paper was prepared within the framework of the research project "New European Crimes and Trust-based Policy" (FIDUCIA), funded by the European Commission through the Seventh Framework Programme for Research and Development (SSH.2011.3.21, Criminal behaviour and policy responses in the European Union. Grant Agreement No. 290563/Fiducia). More information on the FIDUCIA project at www.fiduciaproject.eu/. Last accessed: 5. 12. 2012.

${ }^{1}$ M. Yordanova (Ed.), Crime and Punishment. Studying Justice System for Shaping Criminal Policy. Center for the Study of Democracy, Sofia, 2011, p. 8.

${ }^{2}$ See, among others, A. I. Pérez Cepeda, A. \& C. D. Benito Sánchez, Study on the Existing Tools for Measuring Crime, Revista Brasileira de Ciencias Criminais, 98, 2012, a research also carried out within the framework of the research project "New European Crimes and Trust-based Policy" (FIDUCIA).
} 
In order to improve the reliability of the existing data and to encourage their use in decision-making on criminal matters, the European Union has been working for years on the development of a comprehensive and coherent strategy to measure crime and criminal justice. The next section of this paper presents the most representative work carried out by the European Union in this field, paying close attention to the Stockholm Programme - An Open and Secure Europe Serving and Protecting Citizens, which highlights the necessity of developing reliable data on crime as a prerequisite for evidence-based decisions on a number of matters within the area of freedom, security and justice.

The third section of this paper briefly describes the decision-making process on criminal issues in the European Union. Here, the aim is to achieve two main goals: first, to determine the point in the process at which crime data should be used by policymakers, and, secondly, to identify if the existing crime data are currently being used in the development of criminal policy. With respect to the first goal, we reach the conclusion that the most appropriate point in the policy-making process at which data on crime trends should be examined is the pre-legislative phase. It is at that point that the European Commission, which is in charge of the legislative initiative, can receive the necessary information from experts and civil society. And it is at that point that the use of a mechanism developed during the last decade at the European level, the impact assessment of policies, becomes crucial. The impact assessment of policies is a process aimed at providing evidence for political decisionmakers on the advantages and disadvantages of possible policy options by assessing their potential impact. When developing criminal policy at the European level, impact assessments should reflect the existing data on crime. However, our study shows that, in the first place, the use of impact assessments in criminal matters is currently limited: only five impact assessments have been carried out in this field at the European level. Moreover, the use of crime data within existing impact assessments seems to be very rare: only three of the five impact assessments that have been carried out on criminal matters mention data on crime trends. Although they contain some references to crime data, the need for improvement is underlined.

The fourth section of this work provides a synthesis of the main reasons why the existing data on crime trends are insufficiently imbedded in the European decisionmaking process. For this purpose, a thorough review of the existing literature on the topic was carried out. Moreover, an effort was made to engage European policymakers responsible for developing criminal policy in a discourse on the topic. More precisely, a questionnaire was directed at the members of the Committee on Civil Liberties, Justice and Home Affairs (LIBE), which is responsible for most of the legislation linked to the area of freedom, security and justice, in which they were asked about their views on the shortcomings of existing data on crime trends. Although the questionnaire was sent three times between March and June 2012, unfortunately only one response was received. This fact complicated the development of the fourth section of this paper, since the research had to be based on the existing literature alone. The reasons why the available data on crime trends have 
limited policy-relevance within the decision-making process have been divided into two main groups: 1) reasons related to the limitations of the existing data and 2) reasons related to the policy-making process. And a list of recommendations is provided to overcome the limitations of the existing data and to improve their policy-relevance in the future.

Finally, the main results of this study are summarised in the conclusion.

\section{The need to collect crime data at the European level. Measuring crime in the EU: Statistics Action Plan 2011-2015}

The European Union Strategy for the Beginning of the New Millennium is based on reliable and valid data on organised crime and offenders ${ }^{3}$. Rules on collecting data at the European level are contained in Regulation (EC) No. 223/ 2009 of the European Parliament and of the Council of 11 March 2009, ${ }^{4}$ the objective of which is to establish a legal framework for the development, production and dissemination of European statistics (art. 1). The Community statistical authority responsible for carrying out this legal framework is Eurostat (art. 6). The production of Community statistics is also guided by the Community Statistical Programme 2008-2012 $2^{5}$, Annex II of which includes Title IV, which sets out the need to develop statistics on crime and criminal justice in order to implement the Hague Programme, stressing the need to develop new data sources on organised crime.

\section{Earlier initiatives}

The progressive establishment of the area of freedom, security and justice was a new objective set by the Treaty of Amsterdam for the European Union. Under the Treaty of Amsterdam, the first phase in establishing the area of freedom, security and justice came to an end on 1 May 2004. The Tampere European Council of 1999 had determined the programme of work to be done by then. The Communication from the Commission that assessed that program ${ }^{6}$ stated the following priority, among others, in this area of freedom, security and justice for the fight

\footnotetext{
${ }^{3}$ The Prevention and Control of Organised Crime: A European Union Strategy for the beginning of the New Millennium (Official Journal C124 of 3 May 2000).

${ }^{4}$ Regulation (EC) No. 223/2009 of the European Parliament and of the Council of 11 March 2009 on European statistics and repealing Regulation (EC, Euratom) No. 1101/2008 of the European Parliament and of the Council on the transmission of data subject to statistical confidentiality to the Statistical Office of the European Communities, Council Regulation (EC) No. 322/97 on Community Statistics, and Council Decision 89/382/EEC, Euratom establishing a Committee on the Statistical Programmes of the European Communities (Official Journal L87 of 31 March 2009).

${ }^{5}$ Decision 1578/2007/EC of the European Parliament and the Council of 11 December 2007 on the Community Statistical Programme 2008-2012, which substitutes the Community Statistical Programme 2003-2007 (Community Statistical Programme, as adopted by Decision No. 2367/2002 / EC of the European Parliament and the Council of 16 December 2002 (Official Journal L358 of 31 December 12 2002).

${ }^{6}$ Communication from the Commission to the Council and the European Parliament. Area of Freedom, Security and Justice: Assessment of the Tampere programme and future orientations. COM (2004) 401 final, Brussels, 2 June 2004.
} 
against serious crime: "statistical work and collection of information on the development of crime and public perceptions of the level of security should be improved, in particular through a harmonised information collection system which is structured and regular". The Hague Programme continued working in this direction.

- The Hague Programme: Strengthening Freedom, Security and Justice in the European Union ${ }^{7}$

The Hague Programme provided the rules for establishing policies within the area of freedom, security and justice during the years 2005-2009. Among other issues, the Commission was required to translate the objectives of the Hague Programme into concrete actions contained in an Action Plan based on EU crime statistics, ${ }^{8}$ and to create a group of experts to assist in this task. In addition, in order to enhance security, knowledge of organised crime had to be improved. Also, the gathering and analysis of information had to be strengthened.

- Communication from the Commission to the European Parliament, the Council and the European Economic and Social Committee. Developing a comprehensive and coherent EU strategy to measure crime and criminal justice: An EU Action Plan 2006-2010

The EU Action Plan demanded by the Hague Programme was crystallised in this Communication from the Commission, the aim of which was to tackle the lack of reliable and comparable information on crime trends, levels and structure in Europe. The Communication included a "table of actions", among which particular reference should be made to the establishment of a methodology for a common module of a victimisation survey that would allow reliable comparisons among Member States, and the development of specific indicators in areas related to cross-border crime, such as corruption, counterfeiting and piracy of products, fraud, illicit trafficking in cultural goods, money-laundering, sexual exploitation of children and child pornography, and terrorist financing.

The Commission also established a group of experts to help in implementing the Action Plan:

- Commission Decision of 7 August 2006 setting up a group of experts on the policy need for data on crime and criminal justice ${ }^{10}$

According to this Decision, the group of experts should be composed of individuals competent to consider the policy needs and to advise on the effective use of indicators and data in the area of crime. Article 4 refers to the membership. The expert group should be composed of a maximum of 50 experts chosen from national public authorities in the field of justice and home affairs, and from European bodies, international organisations or non-governmental organisations with relevant experience and expertise in analysing or developing crime and criminal justice data for policy purposes. Individuals with expertise deriving from

\footnotetext{
7 Official Journal C53 of 3 March 2005.

${ }^{8}$ Communication on the Hague Programme: Ten priorities for the next five years - The Partnership for European Renewal in the Field of Freedom, Security and Justice. COM (2005) 184 final, Brussels, 10 May 2005.

${ }^{9}$ COM (2006) 437 final, Brussels, 7 August 2006.

${ }^{10}$ Official Journal L234 of 29 August 2006.
} 
academic research or from the private sector in this field might also become members of the expert group.

The main tasks of the Group were to assist the Commission in establishing cooperation between Member States and other related organisations in implementing the EU Action Plan 2006-2010, to assist the Commission in identifying the policy needs for data on crime and criminal justice at the EU level, to assist the Commission in identifying the needs for the development of common indicators and tools designed to measure crime and criminal justice, to advise the Commission on relevant research and development needs or results to be taken into account in the task to implement the above-mentioned plan, and to advise the Commission on collaboration with representatives from the private and academic sectors or other relevant sectors in order to include relevant knowledge and experience in the task to implement the above-mentioned EU plan.

\section{Current initiatives}

The European Council framed the new strategic objectives until 2014 in the Stockholm Programme.

\section{- The Stockholm Programme - An Open and Secure Europe Serving and Protecting Citizens ${ }^{11}$}

The Stockholm Programme recognises that "adequate, reliable and comparable statistics (both over time and between Member States and regions) are a necessary prerequisite, inter alia, for evidence-based decisions on the need for action, on the implementation of decisions and on the effectiveness of action". Therefore, the European Council invites the Commission to "continue developing statistical tools to measure crime and criminal activities and reflect on how to further develop, after 2010, the actions outlined and partly implemented in the Union Action plan for 2006-2010 on developing a comprehensive and coherent Union strategy to measure crime and criminal justice, in view of the increased need for such statistics in a number of areas within the area of freedom, security and justice". In order to develop this task, the Commission adopted a new Action Plan:

- Communication from the Commission to the European Parliament and the Council. Measuring Crime in the EU: Statistics Action Plan 2011$2015^{12}$

The Action Plan 2006-2010 was the first step in a long-term process. It set the basis for an EU strategy to measure crime and criminal justice by developing a mechanism for the smooth flow of information from and to the Member States. The aim of the new Action Plan 2011-2015 is to continue and take forward the work begun in 2006 and to focus on the delivery of results. The objectives presented in this Action Plan are based on the priorities set by the Internal Security Strategy with regard to specific crime areas and on the recommendations

\footnotetext{
${ }^{11}$ Official Journal C115 of 4 May 52010.

${ }^{12}$ COM (2011) 713 final, Brussels, 18 January 2012.
} 
from the Expert Group on Policy Needs. These objectives are divided into the following four areas:

(1) Cooperation at the EU and international level. The objectives under this category respond to the recommendations of experts for better mapping of the needs of policymakers, better communication with the stakeholders, promotion of the work on crime and criminal justice statistics among the EU institutions, and better collaboration at the EU and international level, in order to avoid duplication of the collection exercises.

(2) Data quality. The objectives of this category aim to improve the comparability of the data that are being produced on a regular basis. Since the main reasons for not having comparable data are the differences in the criminal codes and the reporting systems, the emphasis is on the development of an international crime classification system for statistical purposes, taking account of multilingual needs.

(3) Data analysis and dissemination of results. Because of the differences in recording, reporting and classifying crime across the Member State, comparisons of crime levels can be misleading, especially if absolute figures are not accompanied by additional information on their quality (metadata). Therefore, one of the actions of the Plan refers to the systematic compilation and publication of metadata and contextual information, following the example of Statistics in Focus.

(4) Development of indicators and specific data collections. Within this category, the following types of activities are to be carried out: to implement the EU Safety Survey, the Business Victimisation Survey and the third Money Laundering data collection, to progress in data collection on cybercrime, and to develop indicators on corruption.

The Action Plan also includes the re-establishment and enlargement of the expert group.

\section{- Commission Decision of 14 February 2012 setting up the Commission expert group on policy needs for data on crime and repealing Decision 2006/581/ $\mathrm{EC}^{13}$}

This Decision repeals the previous one from 2006 and sets up the new expert group on policy need for data on crime, which will have similar tasks, as referred to above.

After having revised these instruments adopted by the European Union, we can conclude that they provide a sufficient framework for facilitation of progress in the gathering of crime data at the European level.

\section{Drafting: The decision-making process in criminal law at the Eur- opean level}

This section briefly describes the decision-making process in criminal matters at the European level focusing on the pre-legislative phase, when the available data on

\footnotetext{
${ }^{13}$ Official Journal C42 of 25 February 2012.
} 
crime trends should be used by policymakers in order to develop evidence-based policies.

The Lisbon Treaty abolished the structure of the three pillars on which the TEU was based. From its entry into force, the only legal instrument at the European level is the directive (Art. 83 TFEU), which must be approved by the tripartite institutions: the European Commission, the European Parliament and the Council (Art. 294 TFEU). The aim of the reform carried out by the Lisbon Treaty was to ensure the legitimacy of the rules adopted at the EU level, and at this point, the Treaty opted for the ordinary legislative procedure, which replaces the old co-decision procedure. In the new decision-making procedure, the role of the European Parliament increases and, correspondingly, the role that governments used to play within the old third pillar is reduced. This new situation leads to representative and participatory democracy in the context of federal sovereignty ${ }^{14}$. In the following paragraphs, we examine the main actors in this new procedure.

\section{Actors}

Two types of actors can be distinguished: institutional actors and social actors. The interaction of all of them within the pre-legislative phase leads to necessary deliberative politics in Europe that strengthen the democratic basis ${ }^{15}$.

Regarding the institutional actors, the European Commission is in charge of the legislative initiative, and the European Parliament and the Council are co-legislators. At the previous stage in the ordinary legislative procedure, the European Commission, through consultations with experts and representatives of civil society, draws the necessary information to develop better law. Especially when developing criminal policy, the European Commission should receive information on crime trends during this early stage in the decision-making process.

In addition to the European Commission, Member States also can exercise the right of legislative initiative pursuant to Article 76 TFEU ("on the initiative of a quarter of them"), provided that they respect the principles of proportionality and subsidiarity, and provided that they offer detailed preparation, including impact assessment reports, as called for by the Stockholm Programme.

Regarding the social actors, they interact with the European Commission through the so-called Green and White Papers. A Green Paper is a document meant to invite interested individuals or organisations to a process of consultation and debate on a particular topic. ${ }^{16}$ It may be followed by a White Paper, which represents an official set of proposals that is used as a vehicle for their development into law. ${ }^{17}$

\footnotetext{
${ }^{14}$ C. Gómez-Jara Díez, Constitución europea y Derecho penal: ¿¿Hacia un Derecho penal federal europeo? In $S$. Bacigalupo \& M. Cancio Meliá (Coords.). Derecho penal y Política transnacional, Atelier, Barcelona, 2005, p. 10-11. With respect to representative democracy, see the Lisbon Treaty, which introduces a new Title II called "Provisions on democratic principles".

${ }^{15}$ J. Habermas, Three Normative Models of Democracy, Constellations Vol. I, No. 1, 1994, p. 7-8

${ }^{16}$ Green Papers published since 1993 are available at http://europa.eu/documentation/official-docs/green-papers/ index_en.htm (last accessed: 5. 12. 2012).
} 
At this point, the work of some social actors deserves to be highlighted. One example is the academic group Criminal Policy European Initiative ${ }^{18}$. Its main contribution to the decision-making process in criminal matters at the EU level was the Manifesto on European Criminal Policy, which adopts and defends the ordinary legislative procedure defined in the Lisbon Treaty. Furthermore, the work of organisations such as RAND-Europe should also be noted. It is a nonprofit institution that helps to improve policy- and decision-making through research and analysis. It was commissioned to carry out "The Development of a European Crime Report", a test of how a reliable report on crime trends in Europe should be.

Other public consultations are contained on the EU website, where there is a platform for the initiatives of European citizens through the so-called "Your Voice in Europe"19.

\section{The pre-legislative phase}

The main Anglo-Saxon contribution to the decision-making process in criminal matters at the European level was the introduction of the use of impact assessments as a part of the rational-choice theory based on cost-benefit analysis ${ }^{20}$. Diverse European instruments refer to the need to use impact assessment studies for developing better laws. For example, Article 70 TFEU states that objective and impartial evaluation is an important tool for legislative rationality ${ }^{21}$. Furthermore, the White Paper on European Governance requires that the EU legislative acts are preceded by impact assessments. The impact assessment of policies is a process aimed at preparing evidence for political decision-makers on the advantages and disadvantages of possible options by assessing ex ante their social, economic and environmental impact. The process is divided into two phases: 1) the planning of impact assessments - the roadmap ${ }^{22}$ - and 2) preparing the assessment itself - full impact assessment $-{ }^{23}$. This second phase encompasses six steps: ${ }^{24} 1$. Identification of the problem; 2. Definition of objectives; 3. Development of the main policy options; 4. Analysis of their impacts; 5. Comparison of the options, and 6. Outlining of policy monitoring and evaluation. Impact assessments in criminal matters should in particular reflect a cost-benefit analysis, which is obtained by balancing the deprivation of rights that the imposition of a penalty involves (cost),

\footnotetext{
${ }^{17}$ European Governance. A White Paper. COM (2001) 428 final, Brussels, 25 July 2001.

18 This is an academic group created by fourteen professors of criminal law from fourteen different EU Member States. See http://www.crimpol.eu/ (last accessed: 5. 12. 2012).

${ }^{19}$ See http://ec.europa.eu/yourvoice/index_en.htm (last accessed: 5. 12. 2012).

${ }^{20}$ A. Renda, Impact Assessment in the EU. The State of the Art and the Art of the State, Centre for European Policy Studies, Brussels, 2006, pp. 7 et seq.

${ }^{21}$ A. Nieto Martín, La armonización del Derecho penal ante el Tratado de Lisboa y el Programa de Estocolmo. Revista General de Derecho penal, No. 13, 2010, pp. 6-7.

22 The roadmaps are available at http://ec.europa.eu/governance/impact/planned_ia/roadmaps_2012_en. htm\#JUST (last accessed: 5. 12. 2012).

${ }_{23}$ M. Muñoz de Morales Romero, El legislador penal europeo: legitimidad y racionalidad, Thomson Reuters, Pamplona, 2011 , p. 664.

${ }^{24}$ European Commission: Impact Assessment Guidelines, SEC (2005) 791, 15 June 2005.
} 
against the aim pursued by the imposition of a penalty (benefit), that is the prevention of crime ${ }^{25}$.

The directives provided by the Impact Assessment Guidelines $2009^{26}$ refer to the need for data collection and consultation with stakeholders, stressing that quality data are a key part of any impact assessment. Quality data are needed both to define the problem and to identify the impact of alternative options for dealing with the problem. Therefore, quality data should be used in the impact assessment process relating to a certain policy. Nevertheless, it seems that the use of impact assessments in the field of criminal law is quite rare. Five impact assessment studies have been carried out in criminal matters to date, in relation to intellectual property, the protection of the environment, employers of illegally staying third-country nationals, terrorism, and trafficking in human beings. ${ }^{27}$ Only three of these refer to data on crime trends, and although they contain some references to such data, the need for improvement is underlined.

In particular the impact assessment related to the protection of the environment through criminal law recognises the existence of a significant dark figure in this field, in that the difference between actual crime levels and crime levels known to the authorities can fluctuate between 20 and $40 \%$, and in some cases up to $90 \%$. In addition, this impact assessment points out that the lack of homogeneity among the legal systems of the Member States makes it difficult to measure these offences, since in some Member States such offences are not recorded as environment crime but as company crime.

The impact assessment related to sanctions against employers of illegally staying third-country nationals outlines the different methods, indirect and direct, used by researchers and NGOs in counting the number of irregular persons residing or working, which hampers the determination of the actual figures on such offences. However, this impact assessment also refers to the Regulation of Community statistics on migration and international protection ${ }^{28}$, which envisages the development of common rules for the collection of data on migration by EU Member States.

Finally, the impact assessment on trafficking in human beings uses data obtained from the International Labour Organisation (ILO) and the International Organisa-

\footnotetext{
${ }^{25}$ M. Muñoz de Morales Romero, op. cit., p. 586.

${ }^{26}$ European Commission: Impact Assessment Guidelines, SEC (2009) 92, 15 January 2009.

${ }^{27}$ Document de travail de la Commision Annexe à la Proposition de Décision Cadre du Conseil visant le renforcement du cadre pénal pour la répression des atteintes à la propriété intellectuelle [SEC (2005) 848]. Commission Staff Working Document accompanying document to the Proposal for a Directive on the protection of the environment through criminal law [SEC (2007) 160]. Commission Staff Working Paper accompanying document to Proposal for a Directive of the EP and of the Council providing for sanctions against employers of illegally staying third-country nationals [SEC (2007) 596]. Commission Staff Working Document accompanying document to the Proposal for a Council Framework Decision amending Framework Decision 2002/475/JHA on combating terrorism [SEC (2007) 1424/2]. Commission Staff Working Document Accompanying document to the Proposal for a Council Framework Decision on preventing and combating trafficking in human beings, and protecting victims, repealing Framework Decision 2002/629/ JHA [SEC (2009) 358].

${ }^{28}$ Regulation (EC) 862/2007 of the European Parliament and the Council of 11 July 2007 on Community statistics on migration and international protection and repealing Council Regulation (EEC) 311/76 on the compilation of statistics on foreign workers (Official Journal L199 of 31 July 2007).
} 
tion for Migration (IOM). However, data from these two agencies are not comparable, since the IOM figures refer to victims who have been assisted by the IOM, while the ILO figures refer to an overall estimate of the number of victims.

All in all, as has already been shown, impact assessments on criminal matters rarely use data on crime. One explanation for this may be the present lack of reliable data on the areas of crime within the scope of work of the European Union (Eurocrimes), as will be explained in the following section.

\section{Areas of crime}

Pursuant to Article 83.1 TFUE, "the European Parliament and the Council may, by means of directives adopted in accordance with the ordinary legislative procedure, establish minimum rules concerning the definition of criminal offences and sanctions in the areas of particularly serious crime with a cross-border dimension resulting from the nature or impact of such offences or from a special need to combat them on a common basis. These areas of crime are the following: terrorism, trafficking in human beings and sexual exploitation of women and children, illicit drug trafficking, illicit arms trafficking, money laundering, corruption, counterfeiting of means of payment, computer crime and organised crime".

At present, however, the analysis and understanding of the dimensions and characteristics of these areas of crime is a complex task, since the availability of data on such offences is particularly limited. In fact, if we take a look at the main existing datasets on crime trends $^{29}$, we can readily observe that there are no data on some of the offences mentioned in Article 83.1 TFEU, such as terrorism, sexual exploitation of women and children, and illicit arms trafficking. Regarding the remaining areas of crime, some data exist but they are not very plentiful, as noted in the following paragraphs.

Trafficking in human beings. Trafficking in human beings was covered by the tenth United Nation Survey on Crime Trend and Criminal Justice Systems (UN CTS) for the first time ${ }^{30}$. This dataset only covered statistics on recorded offences and offenders arrested, prosecuted and convicted, based on the definition of the Protocol to Prevent, Suppress and Punish Trafficking in Persons, Especially Women and Children, supplementing the United Nations Convention against Transnational Organized Crime ${ }^{31}$. However, official statistics on recorded crime alone cannot

\footnotetext{
${ }^{29}$ See, among others, A. I. Pérez Cepeda, A. \& C. D. Benito Sánchez, op. cit., where the following crime datasets are analysed: the European Crime and Safety Survey, the European Social Survey, the European Sourcebook of Crime and Criminal Justice Statistics, the European Union Minorities and Discrimination Survey, the Eurostat Crime Statistics (Statistics in focus), the International Crime Victims Survey, the International Self-report Delinquency Study, the International Violence Against Women Survey, and the United Nations Surveys on Crime Trends and Criminal Justice Systems.

${ }^{30}$ A. Alvazzi del Frate, Chapter 4 - Complex crimes. In S. Harrendorf; M. Heiskanen \& S. Malby (Eds.), International Statistics on Crime and Justice, HEUNI-UNODC, Helsinki, 2010, p. 66.

${ }^{31}$ Art. 3 (a): "Trafficking in persons" shall mean the recruitment, transportation, transfer, harbouring or receipt of persons, by means of the threat or use of force or other forms of coercion, of abduction, of fraud, of deception, of the abuse of power or of a position of vulnerability or of the giving or receiving of payments or benefits to achieve the consent of a person having control over another person, for the purpose of exploitation. Exploitation shall include, at a minimum, the exploitation of the prostitution of others or other forms of sexual exploitation, forced labour or services, slavery or practices similar to slavery, servitude or the removal of organs".
} 
measure the extent of trafficking in persons. Therefore, a broader approach to include survey-based data is required ${ }^{32}$.

Illicit drug trafficking. The European Sourcebook of Crime and Criminal Justice Statistics contains detailed information on drug offences and drug trafficking. The definition of "drug offences" is largely uniform, due to international conventions. Where possible, the figures include the cultivation, production, sale, supply, transportation, importation and exportation of drugs, financing of drug operations, consumption, possession of larger quantities and possession of small quantities. "Drug trafficking" means "drug offences which are not in connection with personal use". However, the line between personal use offences and trafficking is not necessarily clear and is defined differently by country ${ }^{33}$.

Also the UN CTS provides figures on drug-related offences and on drug trafficking. "Drug-related crimes" may be understood to mean intentional acts that involve the cultivation, production, manufacture, extraction, preparation, offering for sale, distribution, purchase, sale, delivery on any terms whatsoever, brokerage, dispatch, dispatch in transit, transport, importation, exportation and possession of internationally controlled drugs. "Drug trafficking" may be understood to mean drug offences which are not connected with personal use.

Eurostat Crime Statistics (Statistics in focus) also contains figures on drug trafficking. Specifically, it includes the illegal possession, cultivation, production, supply, transportation, import and export of drugs, and the financing of drug operations.

The International Crime Victims Survey (ICVS) and the European Crime and Safety Survey (EU ICS) asked about perceptions of drug-related problems. The question was: "Over the last 12 months, how often were you personally in contact with drug-related problems in the area where you live? For example seeing people dealing in drugs, taking or using drugs in public places, or by finding syringes left by drug addicts?" However, answers to such questions give little information about actual trends in drug-related problems ${ }^{34}$.

Money laundering. With respect to this offence, only the European Sourcebook shows figures. According to this dataset, money laundering means "specific financial transactions to conceal the identity, source, and/or destination of money or nonmonetary property deriving from criminal activities". Where possible, the figures include receiving and handling illegally obtained (but not stolen) non-monetary property, attempts, but exclude receiving/handling stolen property and violations of the 'know-your-customer' rule (i.e. negligence in identification of a customer's identity or the origin of funds).

\footnotetext{
${ }^{32}$ A. Alvazzi del Frate, op. cit., p. 67.

${ }^{33}$ M. Aebi, B. de Cavarlay, G. Barclay et al, European Sourcebook of Crime and Criminal Justice Statistics - 2010. 4th edition. Den Haag: Boom Juridische Uitgevers, 2010, p. 373.

${ }^{34}$ J. van Dijk, L. van Kesteren \& P. Smit, Criminal Victimisation in International Perspective. Key findings from the 20042005 ICVS and EU ICS. WODC Report 257. The Hague: Boom Jurisishe uitgevers, 2007, p. 95.
} 
Corruption. The tenth UN CTS collected data on bribery and corruption for the first time, based on the definitions of "active" and "passive" bribery included in the United Nations Convention Against Corruption ${ }^{35}$.

The European Sourcebook also includes data on corruption in the public sector. For this offence, definitions vary significantly among countries. Therefore, this dataset uses a standard definition according to which corruption means "offering or accepting financial or any other advantage in exchange for favourable treatment by public officials". Where possible, the figures include active and passive corruption, instigation to corruption, complicity, corruption of domestic officials, corruption of foreign officials, extortion by public officials and offering officials advantages without immediate interest, and attempts. Corruption in the private sector, extortion (except by public officials) and bribery of the electorate are excluded.

The ICVS and the EU ICS only show figures on petty corruption (bribe-seeking by public officials) but they ignore victimisation by grand corruption, a type of crime which is less visible but potentially more damaging. Low prevalence rates on the ICVS-based measure of petty corruption should not be seen as proof that more serious forms of corruption are equally rare $^{36}$.

Counterfeiting of means of payment. Data on this offence was contained only in the tenth UN CTS, which defined "counterfeit currency offences" as "any violation in connection with manufacturing, issuing, uttering, smuggling or trafficking in counterfeit currency".

Computer crime. Figures on this offence were only offered by the European Sourcebook. With respect to this offence, the national legal systems provide very different definitions. Therefore, this dataset uses a standard definition according to which "offences against the confidentiality, integrity and availability of computer data and systems" comprise "unauthorised entry into electronic systems (computers) or unauthorised use or manipulation of electronic systems, data or software". Where possible, the figures include illegal access (i.e. intentional access to a computer system without right), illegal interception (i.e. interception without right, made by technical means, of non-public transmissions of computer data), data interference (i. e. damaging, deletion, deterioration, alteration or suppression of computer data without right), system interference (i.e. serious hindering without right of the functioning of a computer system), misuse of devices (i.e. production, sale, procurement for use, import, or distribution of a device or a computer password/access code), computer fraud (i.e. deception of a computer instead of a human being) and attempts, but exclude the illegal downloading of data or programs.

\footnotetext{
35 "Active bribery" is defined as "the promise, offering or giving, to a public official, directly or indirectly, of an undue advantage, for the official himself or herself or another person or entity, in order that the official act or refrain from acting in the exercise of his or her official duties" (Art. 15 (a). "Passive bribery" is defined as "the solicitation or acceptance by a public official, directly or indirectly, of an undue advantage, for the official himself or herself or another person or entity, in order that the official act or refrain from acting in the exercise of his or her official duties" (Art. 15 (b).

${ }^{36}$ J. van Dijk, L. van Kesteren \& P. Smit, op. cit., p. 90.
} 
Organised crime. The tenth UN CTS showed for the first time figures on participation in organised crime groups, based on the definition included in the United Nations Convention against Transnational Organized Crime ${ }^{37}$. Statistics were collected at the police, prosecution and courts level but only a few countries were able to respond to the questions on this type of crime. In fact, more than half of the responses to the tenth UN CTS lacked this information ${ }^{38}$.

To sum up, although some data on the types of crime mentioned in article 83.1 TFUE are showed in the datasets mentioned above, they are not comprehensive enough and most of them come from official statistics on recorded crime. Thus, they suffer from the well-known flaws of these statistics (different legal definitions, different recording and reporting practices, the dark figure). Consequently, it becomes difficult to develop evidence-based policy in these areas.

\section{Analyzing the policy-relevance of existing crime data: Flaws and proposals for improvement}

Developing evidence-based criminal policy requires, first of all, the existence of reliable data on crime. At present there are many organisations at the European level and worldwide that collect data on crime. Nevertheless, the existing data suffer from some limitations and therefore they are usually not used at the policy level. In addition, the policymaking process has certain characteristics (such as timing and the pressure exerted by interest groups) that hamper the proper use of existing crime data. This section explores these two sets of reasons (related to the limitations of the data and related to the policymaking process) as to why existing crime data has limited policy relevance, and offers some proposals for improvement.

\section{Reasons related to the limitations of the existing data}

Existing crime data are currently limited due to the following factors: the existence of obstacles for performing comparisons on crime trends between countries or within a country over time, the inaccuracy of the data, the form in which data are presented to policymakers, and the absence of data on so-called "emerging crimes".

\section{a) Difficulties in making comparisons across countries and over time}

Comparisons provide real opportunities for countries to challenge themselves and learn from others. However, the main tool currently used in making comparisons between countries or within a country over time - the official crime statistics on recorded crime - suffers from some shortcomings. Specifically, the existence of

\footnotetext{
37 "Participation in organized criminal groups" may be understood as participating in the activities of an organized criminal group and/or organizing, directing, aiding, abetting, facilitating or counselling serious crimes involving organized criminal groups. This definition may apply to anyone who, being aware of the group's criminal objectives, becomes involved in activities that contribute to the achievement of such objectives.

${ }^{38}$ A. Alvazzi del Frate, op. cit., p. 72.
} 
statistical, legal and substantive factors influences the outcome of such official statistics. In addition, they only reflect recorded crime, and ignore the dark figure of crime. Furthermore, they do not offer contextual information on other factors that may influence the commission of a crime. These three factors are explained below.

\section{- The influence of statistical, legal and substantive factors}

In his review of rape statistics in Sweden, von Hofer $^{39}$ identified three different factors (statistical, legal and substantive factors) that affect official crime statistics to such an extent that making reliable comparisons across countries or within a country over time becomes complicated. Statistical factors refer to the way in which crime statistics are developed. Legal factors include the way the crime itself is defined in the relevant legislation, as well as various related aspects of the judicial process. Finally, substantive factors refer to the propensity to report and to record offences, and to the actual crime levels. Each of these factors can be broken into a number of points that affect comparability.

\section{aa) Statistical factors include the following:}

(1) The point at which the data are collected. On the basis of the moment at which data are collected, countries can be divided into three groups: countries using input statistics, countries using intermediate statistics, and countries using output statistics $^{40}$. In countries using input statistics, data are recorded for statistical purposes when the offence is reported to the police (or when police officers observe or discover an offence). In countries using output statistics, on the contrary, data are recorded when the police have completed the investigation. Finally, some countries record data at an intermediate stage of the process. The point at which data are collected can have a significant effect on the statistics. For instance, Aebi's study shows that countries using input statistics present higher crime rates than those using intermediate statistics, and the latter present higher crime rates that those using output statistics.

(2) The manner in which offences are counted. For instance, particular problems appear when a criminal event includes more than one offence or when more than one person was involved in the event ${ }^{41}$.

(3) The moment to which the statistics refer. For example, statistics may refer to the year when the offence was committed or to the year when the offence was reported ${ }^{42}$.

(4) Changes in statistical routines. If a country modifies its statistical routines, it will be difficult to know whether subsequent changes in the statistics reflect a

\footnotetext{
${ }^{39}$ H. von Hofer, Crime Statistics as Constructs: The Case of Swedish Rape Statistics. European Journal on Criminal Policy and Research 8, 2000.

${ }^{40}$ M. Aebi, Measuring the Influence of Statistical Counting Rules on Cross-National Differences in Recorded Crime, in K. Aromaa \& M. Heiskanen (Eds.), Crime and Criminal Justice Systems in Europe and North America 19952004, HEUNI publication No. 55, Helsinki, 2008, p. 209.

${ }^{41}$ H. von Hofer, op. cit., p. 79.

${ }^{42}$ H. von Hofer, op. cit., p. 80.
} 
modification in the actual crime levels or if these changes are simply a consequence of the modification of the statistical routines ${ }^{43}$.

\section{bb) Legal factors include the following:}

(1) The significance of legal definitions. A crucial problem when making comparisons between countries is the existence of different definitions of the types of crimes. Although definitions of some types of crime are relatively clear (for instance, homicide), for other types of crime it is difficult to understand what type of activities fit into them. This applies not only to unconventional crimes such as organised crime or corruption ${ }^{44}$, but also to some conventional crimes such as rape $^{45}$, theft ${ }^{46}$ or drunken driving.

(2) The effect of the legal process. Statistics may be affected by the role attributed to the victim in the prosecution of the crime. For instance, there are crimes which are only prosecuted if the victim is prepared to press charges, and so if the victim is not prepared to do so, the criminal event may not be registered as a crime $^{47}$.

(3) The "legality principle" as opposed to the "expediency principle". Statistics may also be affected by the power given to the prosecution authority. In systems governed by the "legality principle", the police and the prosecution authorities are required to prosecute all offences of which they become aware. This can lead to the more frequent registration of offences as compared to systems ruled by the "expediency principle", where prosecution is within the discretion of prosecutors and where the classification of offences is negotiable ${ }^{48}$.

\section{cc) Substantive factors include:}

(1)) The propensity of the population to report offences. The propensity of the population to report offences depends on several factors. For instance, it may depend on the level of confidence that the public has in the police and judicial authorities, on the taboos associated with some offences in some countries (i.e. rape), on having access to a telephone, or on the seriousness of the crime ${ }^{49}$. Such factors can make it appear as though these countries have higher actual crime rates, although in fact the people only have a stronger propensity to report crimes.

\footnotetext{
${ }^{43}$ H. von Hofer, op. cit., p 81; R. Zauberman, Surveys on victimation and security in Europe, in Assessing Deviance, Crime and Prevention in Europe, SNEL, Belgium, 2008, p. 35.

${ }^{44}$ S. Malby, Data collection on [new] forms and manifestations of crime, in M. Joutsen (Ed.), New Types of Crime. Proceedings of the International Seminar held in connection with HEUNI's thirtieth anniversary, Helsinki 20 October 2011, HEUNI publication no. 74, Helsinki 2012, p. 120.

${ }^{45}$ H. von Hofer, op. cit., p. 81-82.

${ }^{46}$ G. Barclay, The Comparability of Data on Convictions and Sanctions: Are International Comparisons Possible?, European Journal on Criminal Policy and Research 8, 2000, p. 16.

${ }^{47}$ H. von Hofer, op. cit., p. 83.

${ }^{48}$ H. von Hofer, op. cit., p. 84.

${ }^{49}$ See, among others, H. Goudriaan, J. Lynch \& P. Nieuwberta, Reporting to the Police in Western Nations: A Theoretical Analysis of the Effects of Social Context, Justice Quarterly, Vol. 21, No. 4, 2004, p. 939; H. von Hofer, op. cit., p. 85 .
} 
(2) The propensity of the police to register offences. The propensity of the police to register offences also varies from one country to another. For example, sometimes, political pressure may encourage the police to record all individual incidents in serial offence cases, even if their number needs to be extrapolated, which leads to the appearance of higher crime rates ${ }^{50}$.

(3) The actual crime levels. Finally, one cannot forget that there are many factors which influence the commission of a crime, and therefore the actual crime levels vary across countries and within a country over time ${ }^{51}$.

Aebi adds to the above list of different factors the category of "criminal policy factors" ${ }^{, 2}$, which refer to the crime and crime prevention policies applied by a country, something which may affect the other three factors mentioned. For instance, the application of a zero-tolerance policy should presumably lead to an increase in the offences recorded by the police, at least during the first months of its application, because if the police are interested in every offence, the number of recorded offences should increase.

\section{Recommendations:}

Although collecting comparable data on registered crime is a complicated task, there may still be room for cautious optimism. One of the most frequently repeated proposals for achieving the comparability of crime data is the adoption of standard definitions of the types of offences to be used in the international datasets ${ }^{53}$. One step in this direction has been taken, for example, by the authors of the European Sourcebook of Criminal and Criminal Justice Statistics, who have established standard definitions of the different types of crime and have broken down the offences in special items to be included or excluded ${ }^{54}$.

Standard definitions are needed not only for conventional crimes (burglary, rape, theft) but also, albeit a much more complicated task, of emerging crimes such as corruption, cybercrime and transnational organised crime.

In addition, in order to improve the comparability of the data, counting rules, which vary from country to country, should also be standardised. Once again, the European Sourcebook has tried to address this challenge by offering summarised information on the following questions: 1. Are there written rules regulating the way in which data are recorded? 2. When are the data collected for the statistics? 3. What is the counting unit used in the statistics? 4. Is

\footnotetext{
${ }^{50}$ P. Hunt, B. Kilmer \& J. Rubin, Development of a European Crime Report. Improving Safety and Justice with Existing Crime and Criminal Justice Data, RAND Corporation, 2011, p. 46.

${ }^{51}$ H. von Hofer, op. cit., p. 87

${ }^{52}$ M. Aebi, Methodological Issues in the Comparison of Police-Recorded Crime Rates. In S. Shoham, P. Knepper $\&$ M. Kett (Eds.), International handbook of criminology. Boca Raton: CRC Press, 2010, p. 213

${ }^{53}$ See, among others, M. Aebi, M. Killias \& C. Tavares, Comparing Crime Rates: The International Crime (Victim) Survey, the European Sourcebook of Crime and Criminal Justice Statistics, and the Interpol Statistics. International Journal of Comparative Criminology 2, 2002; S. Harrendorf, Offence Definitions in the European Sourcebook of Crime and Criminal Justice Statistics and Their Influence on Data Quality and Comparability, European Journal on Criminal Policy and Research 18, 2012, p. 24; J. Jehle, How to improve the international comparability of crime statistics, in Joutsen, M. (Ed.), New Types of Crime. Proceedings of the International Seminar held in connection with HEUNI's thirtieth anniversary, Helsinki 20 October 2011, HEUNI publication no. 74, Helsinki 2012, p. 135.

${ }^{54}$ M. Aebi; B. de Cavarlay; G. Barclay et al, op. cit., p. 341 et seq.
} 
a principal offence rule applied? 5. How are multiple offences counted? and 6. How is an offence committed by more than one person counted? ${ }^{55}$.

- The dark figure

Already during the first half of the nineteenth century, when the first statistics on crime were developed, the problem of the dark figure of the criminality was recognised. Almost two centuries later, official statistics on recorded crime continue to face this problem since, by definition, they only reflect crime which has come to light, that is crime discovered by the victims (or by the police), reported to and subsequently recorded by the police. The existence of such a hidden figure, which is ignored by the official statistics on recorded crime, notoriously hinders performing comparisons since the real crime levels are unknown.

\section{Recommendation:}

In order to fill the gap derived from the existence of the dark figure on crime, it would be necessary to use victimisation surveys such as the International Crime Victims Survey (ICVS) or the European Crime and Safety Survey (EU ICS).

- The lack of contextual information when presenting data on crime trends

Crime does not happen in isolation from other factors. In fact, there is a huge number of circumstances that influence crime. For instance, Hunt et al. ${ }^{56}$ highlight three groups of contextual factors which need be taken into consideration when interpreting the existing data on crime trends: a) opportunities for committing a crime and for becoming victim of a crime (population density, science, technology), b) facilitating factors (social capital, social networking, social exclusion indicators) and c) private sector involvement. However, the main existing datasets on crime, such as the European Sourcebook of Crime and Criminal Justice Statistics, the UN Surveys on Crime Trends and Criminal Justice Systems or the International Crime Victim Survey do not provide contextual information which may help the users to understand crime trends and which may consequently lead policymakers to improved crime policies.

Recommendation:

More reliable comparisons could be made if contextual information was gathered. Even if definitions of the types of crime and counting rules could be standardised, there are other circumstances that may influence the crime rates. On this point, Hunt et al. ${ }^{57}$ suggest collecting information at the macro, meso and micro levels. Examples of macro-level factors are the economic context and demographic characteristics such as age and gender; meso-level factors include changes in criminal justice systems and other infrastructural changes and practices such as changes in alcohol pricing and availability; and micro-level factors include peer affiliations and close relationships, attachment to moral codes, parenting and social support.

\footnotetext{
55 M. Aebi, Measuring ..., op. cit., p. 201.

${ }^{56}$ P. Hunt, B. Kilmer \& J. Rubin, op. cit., p. 21.

${ }^{57}$ P. Hunt, B. Kilmer \& J. Rubin, op. cit., p. 52-53.
} 


\section{b) Lack of accuracy or mistrust}

The lack of accuracy or mistrust in the data, which may be related to the capability (experience or expertise) of those responsible for validating the data, may be a reason that helps to explain the limited policy-relevance of existing crime data $^{58}$.

\section{Recommendations:}

In order to address such a challenge, it would be desirable that the working group validating data includes experienced persons, as is the case with the European Sourcebook project ${ }^{59}$.

Any research faces limitations which policymakers and the public at large are aware of. Therefore, another way to increase trust in the data might be that the authors of a crime dataset supply information about the limitations of the data and analysis ${ }^{60}$. For example, the authors of the European Sourcebook admit that "the lack of uniform definitions of offences, of common measuring instruments and of common methodology makes comparisons between countries extremely hazardous ${ }^{\prime 61}$. It does not make the research invalid since the European Sourcebook also provides indications of how in the opinion of experts the data can be interpreted. In fact, the European Sourcebook contains numerous footnotes and technical information explaining the figures in each table in order to avoid misinterpretation of data. However, although we consider it necessary to give warning regarding the potential limitations of one data source, the communication of such limitation has to be cautious because if they are not communicated properly, the users may think that the data are of poor quality and not worth using ${ }^{62}$.

\section{c) The form in which crime data is presented to policymakers}

Crime data is generally not produced in a form that senior policymakers can understand and use. A good example of this is the European Sourcebook of Crime and Criminal Justice Statistics. It is a treasure trove for criminologists and others who use crime data on a regular basis. Nevertheless, policymakers are not usually interested in such in-depth analysis but in readily available statistics, such as the way the rate of a particular crime has changed over a certain period of time. Therefore, the abundance of footnotes and explanatory remarks within the European Sourcebook makes it very difficult for policymakers to read.

\section{Recommendation:}

Since policymakers do not need the same level of detailed information that academics may need for their purposes, crime data should be presented to policymakers in a comprehensible form; for instance, readily intelligible pieces of information with visual representations (such as graphs) showing changes in crime rates over a certain period of time would be useful for them ${ }^{63}$. However, the simplifying of crime data should be done carefully in order to avoid an oversimplification that can be misleading for the reader.

\footnotetext{
58 Ibid. p. 47.

${ }^{59}$ Ibid.

${ }^{60}$ Ibid.

${ }^{61}$ M. Aebi, B. de Cavarlay, G. Barclay et al, op. cit., p. 22.

${ }^{62}$ P. Hunt, B. Kilmer \& J. Rubin, op. cit., p. 47.

${ }^{63}$ Ibid. p. 12.
} 


\section{d) The lack of data on "emerging crimes"}

One of the main shortcomings of the existing crime datasets is the lack of comprehensive data on so-called "emerging crimes", "complex crimes" or "new crimes". Typically, data sources on crime show figures on conventional crimes such as homicide, rape, burglary or theft, but they usually do not show figures on nonconventional offences such as corruption, terrorism or trafficking in human beings. This fact seems to be due to the difficulty in formulating clear and widely accepted definitions of such crimes, which are usually composed of more than one single action, and which are usually committed by groups of persons meeting the definition of an organised criminal group contained in Art. 2 (a) of the United Nations Convention against Transnational Organized Crime ${ }^{64}$. The lack of comprehensive data on such offences may also be due to the fact that they are considered victimless crimes (except terrorism and trafficking in human beings), meaning that they do not harm an individual person but harm collective interests. Thus people do not feel individually damaged by them and hence such crimes do not appear either in official statistics on recorded crime or in the findings of victimisation surveys carried out among households ${ }^{65}$. For this reason, official statistics on such crimes may be misleading for the reader; for example, in countries where organised crime is most prevalent, investigations into such crimes might be hampered by police corruption and political interference in prosecuting and sentencing. Therefore, low rates of court cases involving such crimes may paradoxically point to high rather than low prevalence of this type of crime ${ }^{66}$.

It is especially necessary to point out here the absence of comprehensible data on the so-called Eurocrimes ${ }^{67}$ (see section 3.3): terrorism, trafficking in human beings and sexual exploitation of women and children, illicit drug trafficking, illicit arms trafficking, money laundering, corruption, counterfeiting of means of payment, computer crime and organised crime (Art. 83.1 TFEU). If policymakers at the European level do not have data on these types of crime, it will be impossible to develop evidence-based policies related to them.

\section{Recommendation:}

Given the absence of comprehensive data on emerging crimes (including Eurocrimes), there is at present an urgent need to gather reliable data on such crimes. This is not an easy task due to the lack of clear and widely accepted definitions concerning most of these offences and due to the fact that most of them are victimless crimes. Nevertheless, in recent years, efforts to develop indicators regarding these new crimes have been made ${ }^{68}$, and this trend has to continue in order to provide policymakers with reliable data for developing evidence-based policies in this field.

\footnotetext{
${ }^{64}$ S. Malby, op. cit., p. 120.

${ }^{65}$ S. Malby, op. cit., p. 123, J. van Dijk, The International Crime Victims Survey and Complementary Measures of Corruption and Organised Crime. Crime Prevention Studies, volume 22, 2007, p. 131.

${ }^{66}$ J. van Dijk, Mafia markers: assessing organized crime and its impact upon societies. Trends in Organized Crime 10 , 2007 , p. 40.

${ }^{67}$ See section 3.3 .

${ }^{68}$ S. Malby, op. cit., p. 123-125; J. van Dijk, Mafia markers..., op. cit.; J. van Dijk, op. cit.
} 


\section{e) Lack of a place on the Internet where the most representative datasets on crime are put together}

As was already mentioned, there are currently many datasets on crime trends at the European level and worldwide. Nevertheless, there are few places for interested parties to go where the information is brought together. Likewise, there is no place where stakeholders can access other useful information that helps in understanding the crimes, such as information on the national legal systems and counting rules, and on contextual factors from each country that influence the crime rates.

\section{Recommendation:}

Since there are currently a large number of datasets on crime, it would be useful to create the possibility to access them on one website, since the Internet is the current key medium for the presentation and exchange of information. Thus it would be desirable to design a place on the Internet through which users could have access not only to crime data, but also to other crucial information such as information on the national legal systems and counting rules, and on contextual factors from each country that influence the commission of a crime ${ }^{69}$. This would be a crime data portal through which the crime research community could contribute, and where they could offer a critique and comment on the data and any analysis made on its basis. Properly moderated, it could in time become reasonably authoritative, the "go-to" place where national and international policymakers could obtain data.

\section{Reasons related to the policymaking process}

\section{a) The disconnection between policymakers and researchers}

A key role of research is to inform policymaking. However, getting research to influence practice is not an easy task due to the traditional existing disconnection between policymakers and researchers. Policymakers are not usually involved in research projects. Thus researchers often have to imagine what policymakers need to know in designing policies, and they have to carry out their research without knowing whether this research will be useful for the policymakers. A good example of such a disconnection is our vain attempt to carry out a brief survey on the shortcomings of the existing crime datasets among the members of the Committee on Civil Liberties, Justice and Home Affairs (LIBE), which is in charge of most of the legislation linked to the area of freedom, security and justice in the EU. Although the survey was e-mailed to the 24 members three times, we only received one response. This hampered the achievement of the objectives of our research, since the research had to be based on the existing literature alone.

\section{Recommendations:}

It is necessary to encourage cooperation between policymakers and researchers in order to improve the transfer of knowledge. Policymakers should be involved in research projects from the outset in order to tell the researchers what they need to know and when they need to know

\footnotetext{
${ }^{69}$ P. Hunt, B. Kilmer \&J. Rubin, op. cit., p. 71 et seq.
} 
it. This early involvement is essential since the simply passive dissemination of research findings is not sufficient to ensure that research findings will be used to improve policy ${ }^{70}$.

Especially at the European level, it is essential that EU policies benefit from the knowledge coming out of research projects funded by the EC, once again underlining the need for involving European policymakers in such projects from the very beginning.

\section{b) Policymaking timing versus research timing}

The pace of policymaking is clearly faster than that of scientific research. Policymakers usually have very little time to study an issue. In comparison, the results of scientific research may not be available until after years of research. This is the case with some of the existing datasets on crime trends. For instance, the European Sourcebook of Crime and Criminal Justice Statistics and the results of the International Crime Victims Survey are published every three or four years - which amounts to an eternity in policy formulation.

In addition, the rapid pace of policymaking hinders policymakers from having the necessary time to understand the limitations of research and the limits on how data can be used.

\section{Recommendations:}

High frequency statistics would be necessary to allow policymakers the possibility of rapid intervention on certain issues ${ }^{71}$. Obviously, this requires allocation of sufficient funds.

On the other hand, as was mentioned above, policymakers do not need enormous amounts of data. They do need analysis of the information that can help them to design better criminal policy. Therefore, researchers should be encouraged to analyse the data with scientific methods and provide politicians with specific policy suggestions.

\section{c) The pressure from interest groups}

Policymakers are usually under pressure from a number of different interest groups. Many of these interest groups will be brandishing their own data to support their position. There is no reason for the policymakers to assume that researchers are impartial, and that the data they show has not been skewed by the researchers to serve the researchers' own view on matters. Even policymakers have often heard that statistics can be misleading ("lies, damned lies, and statistics"), and therefore they may be sceptical of statistics and simply ignore them.

Furthermore, policymakers may also be under pressure from the public at large which appears to demand quick and punitivist responses against a particularly serious offence, even though the data do not show an increase in the rate of such crime.

\footnotetext{
${ }^{70}$ National Audit Office - NAO, Getting the evidence: Using research in policy making, London, 2003, p. 7; T. Tydén, E D. Nordfors, INFOPAC - Researchers Learn Research Dissemination by Doing, Science Communication, vol. 21, No. 23, March, 2000.

${ }^{71}$ W. De Wever, Crime and deviance in the EU. Key findings from EU funded social sciences and humanities research projects, European Commission, Directorate-General for Research and Innovation, Socio-economic Sciences and Humanities, Brussels, 2011, p. 29.
} 


\section{Recommendations:}

It is clear that policymakers should not develop criminal policy based on poor quality data. They should employ data coming from organisations which have experts in validating the data in their working groups.

Criminal policy in a democratic society should not be based on the sentiments that certain offences might evoke in the public but on evidence borne out of reliable research.

To sum up, the recommendations that we have introduced here will finally allow existing crime data to be understood by policymakers and be applied leading to better policy decisions.

\section{Conclusion}

In recent years, we have heard repeated calls nationally and internationally for evidence-based policy. The starting point of evidence-based criminal policy is, without doubt, the existence of reliable data on crime. However, available data, especially that coming from police statistics on recorded crime, suffer from certain flaws such as various statistical, legal and substantive factors that misrepresent the amount, structure and trend of crime. This fact reduces its utility for policymakers or researchers when developing criminal policy strategies. In order to address such flaws, measures such as the adoption of standard definitions of specific types of crimes and standard counting rules, the collection of contextual data to which crime is related, or the use of victimisation surveys have been demanded by researchers for a long time. The EU has also been calling for the adoption of measures to improve the collection of data on crime. For instance, the Statistics Action Plan 2011-2015 focuses on four crucial areas: cooperation at the EU and the international level, data quality, data analysis and dissemination of results, and development of indicators and specific data collections. This instrument provides a framework that should facilitate progress in collecting reliable crime data.

The existing datasets on crime trends also have another important weakness: they only offer figures on conventional crimes, ignoring the "new" crimes and the socalled victimless crimes. In our analysis of the most relevant existing datasets, we have observed in particular the lack of data on Eurocrimes: terrorism, trafficking in human beings and sexual exploitation of women and children, illicit drug trafficking, illicit arms trafficking, money laundering, corruption, counterfeiting of means of payment, computer crime and organised crime. This fact obviously hampers the development of evidence-based policies in the areas of crime within the scope of the work of the European Union. For this reason, we consider the gathering of data on such offences to be essential. The starting point here should be the adoption of clear definitions and then, the development of indicators to measure trends in such offences since the traditional tools (official statistics on recorded crime and victimisation surveys among households) seem to be insufficient.

Whenever reliable data on such crimes will be available, it will be necessary to fill the gap between policymaking and research in order to undertake evidence- 
based crime policies which take into account such data. In section 4.2 of this paper, we have analysed the main reasons that explain the existence of such a gap: 1) The traditional disconnection between policymakers and researchers. For example, policymakers are not usually involved in research projects. For this reason, researchers often have to imagine what policymakers need to know in designing their policies. 2) The pace of policymaking is clearly faster that that of scientific research, and so policymakers usually have very little time to study the available data and they have much less time to understand the limits to how data can be used. 3) The existence of interest groups, lobbies or think tanks which offer policymakers their own data to support their positions. In this context, policymakers assume that such data are not impartial and they may readily ignore even research-based data.

We have presented some proposals designed to fill the existing gap between policymaking and research. On the one hand, policymakers should be involved in research projects on crime since the outset, in order to inform researchers about what kind of evidence they need to know. In particular in the framework of the European Union, policymakers should participate in projects funded by the European Commission. On the other hand, researchers should analyse the data with scientific methods, and summarise and communicate them to policymakers in a way that makes the evidence comprehensible and accessible to policymakers. Raw data need not be communicated to policymakers since policymakers may not understand them and do not need such in-depth information. Policymakers should base their criminal policy on analysis that reflects the reality in society, and not on sentiments apparently expressed by the public at large or on the pressure exerted by certain interest groups.

The EU is moving in this direction. Over the last decade a mechanism has been developed with the aim of incorporating the use of data in the decision-making process: the impact assessment of policies, which is a process aimed at preparing evidence for political decision-makers on the advantages and disadvantages of possible policy options by assessing their potential impact. However, only five impact assessment studies in criminal matters have been undertaken to date - a very small number. Only three of them (in the fields of protection of the environment through criminal law, employers of illegally staying third-country nationals and trafficking in human beings) mention data on crime trends, and although these three make some references to such data, the need for improvement is highlighted. Therefore, it would be desirable that impact assessments accompany every EU directive on criminal issues. This would a good tool for developing evidence-based criminal policy which takes into account the actual crime levels. Over the last decade a mechanism has been developed with the aim of incorporating the use of data in the decision-making process: the impact assessment of policies, which is a process aimed at preparing evidence for political decision-makers on the advantages and disadvantages of possible policy options by assessing their potential impact. However, only five impact assessment studies in criminal matters have been under- 
taken to date - a very small number. Only three of them (in the fields of protection of the environment through criminal law, employers of illegally staying thirdcountry nationals and trafficking in human beings) mention data on crime trends, and although these three make some references to such data, the need for improvement is highlighted. Therefore, it would be desirable for impact assessments to accompany every EU directive on criminal issues. This would be a good tool for developing evidence-based criminal policy which takes actual crime levels into account. However, criminal policy developed by policymakers should not be influenced solely by the information provided by empirical data on actual crime levels. It should also take into consideration criteria of justice and, ultimately, it should find its limits in the principles of the social and democratic rule of law contained in our constitutions.

\section{References}

Aebi, M. \& Linde, A. (2012). Conviction Statistics as an Indicator of Crime Trends in Europe from 1990 to 2006. European Journal on Criminal Policy and Research 18: 103-144.

Aebi, M. (2008). Measuring the Influence of Statistical Counting Rules on Cross-National Differences in Recorded Crime, in Aromaa, K. \& Heiskanen, M. (Eds.), Crime and Criminal Justice Systems in Europe and North America 1995-2004, HEUNI publication No. 55, Helsinki: pp. 200-218.

Aebi, M. (2010). Methodological Issues in the Comparison of Police-Recorded Crime Rates. In Shoham, S.; Knepper, P. \& Kett, M. (Eds.). International handbook of criminology. Boca Raton: CRC Press: 211-222.

Aebi, M.; de Cavarlay, B.; Barclay, G. et al. (2010). European Sourcebook of Crime and Criminal Justice Statistics - 2010. 4th edition. Den Haag: Boom Juridische Uitgevers. Available online at: http://www.europeansourcebook.org/ob285_full. pdf (last accessed: 5. 12. 2012).

Aebi, M.; Killias, M. \& Tavares, C. (2002). Comparing Crime Rates: The International Crime (Victim) Survey, the European Sourcebook of Crime and Criminal Justice Statistics, and the Interpol Statistics. International Journal of Comparative Criminology 2(1): 22-37.

Alvazzi del Frate, A. (2010). Chapter 4 - Complex crimes. In Harrendorf, S.; Heiskanen, M. \& Malby, S. (Eds.) (2010). International Statistics on Crime and Justice, HEUNI-UNODC, Helsinki: 65-73.

Barclay, G. (2000). The Comparability of Data on Convictions and Sanctions: Are International Comparisons Possible?, European Journal on Criminal Policy and Research 8: 13-26.

De Wever, W. (2011). Crime and deviance in the EU. Key findings from EU funded social sciences and humanities research projects, European Commission, DirectorateGeneral for Research and Innovation, Socio-economic Sciences and Humanities, Brussels. 
Gómez-Jara Díez, C. (2005). Constitución europea y Derecho penal: ¿Hacia un Derecho penal federal europeo? In Bacigalupo, S. \& Cancio Meliá, M. (Coords.). Derecho penal y Política transnacional, Atelier, Barcelona: 153-20.

Goudriaan, H.; Lynch, J. \& Nieuwbeerta, P. (2004). Reporting to the Police in Western Nations: A Theoretical Analysis of the Effects of Social Context, Justice Quarterly, Vol. 21, No. 4: 933-969.

Habermas, J. (1994). Three Normative Models of Democracy, Constellations Vol. I, No. 1, p. 7-8.

Harrendorf, S. (2012). Offence Definitions in the European Sourcebook of Crime and Criminal Justice Statistics and Their Influence on Data Quality and Comparability, European Journal on Criminal Policy and Research 18: 23-53.

Hunt, P.; Kilmer, B \& Rubin, J. (2011). Development of a European Crime Report. Improving Safety and Justice with Existing Crime and Criminal Justice Data, RAND Corporation. Available online at http://www.rand.org/pubs/technical_reports/ TR936.html (last accessed: 5. 12. 2012).

Jehle, J. (2012). How to improve the international comparability of crime statistics, in Joutsen, M. (Ed.), New Types of Crime. Proceedings of the International Seminar held in connection with HEUNI's thirtieth anniversary, Helsinki 20 October 2011, HEUNI publication no. 74, Helsinki 2012: 134-138. Available at http://www. heuni.fi/Etusivu/Publications/ (last accessed: 5. 12. 2012).

Malby, S. (2012). Data collection on [new] forms and manifestations of crime, in Joutsen, M. (Ed.), New Types of Crime. Proceedings of the International Seminar held in connection with HEUNI's thirtieth anniversary, Helsinki 20 October 2011, HEUNI publication no. 74, Helsinki 2012: 120-133. Available at http://www.heuni.fi/Etusivu/Publications/ (last accessed: 5. 12. 2012).

Muñoz de Morales Romero, M. (2011). El legislador penal europeo: legitimidad y racionalidad, Thomson Reuters, Pamplona.

National Audit Office - NAO (2003). Getting the evidence: Using research in policy making, London.

Renda, A.; (2006). Impact Assessment in the EU. The State of the Art and the Art of the State, Centre for European Policy Studies, Brussels.

Tydén, T. \& Nordfors, D. (2000). INFOPAC - Researchers Learn Research Dissemination by Doing, Science Communication, vol. 21, No. 23, March: 296-308.

van Dijk, J. (2007 a). Mafia markers: assessing organized crime and its impact upon societies. Trends in Organized Crime 10: 39-56.

van Dijk J. (2007 b). The International Crime Victims Survey and Complementary Measures of Corruption and Organised Crime. Crime Prevention Studies, volume 22: $125-144$.

van Dijk, J.; van Kesteren, L. \& Smit, P. (2007). Criminal Victimisation in International Perspective. Key findings from the 2004-2005 ICVS and EU ICS. WODC Report 257. The Hague: Boom Jurisishe uitgevers. Available online at: http://english. wodc.nl/onderzoeksdatabase/icvs-2005-survey.aspx?cp $=45 \& c s=6796$ (last accessed: 5. 12. 2012). 
von Hofer, H. (2000). Crime Statistics as Constructs: The Case of Swedish Rape Statistics. European Journal on Criminal Policy and Research 8: 77-89.

Yordanova, M. (Ed.) (2011). Crime and Punishment. Studying Justice System for Shaping Criminal Policy. Center for the Study of Democracy, Sofia.

\section{Legal and political documents (in alphabetical order)}

Commission Decision of 14 February 2012 setting up the Commission expert group on policy needs for data on crime and repealing Decision 2006/581/EC (2012/C 42/92) (Official Journal C42 of 15 February 2012).

Commission Decision of 7 August 2006 setting up a group of experts on the policy need for data on crime and criminal justice (2006/581/EC) (Official Journal L234 of 29 August 2006).

Commission Staff Working Document accompanying document to the Proposal for a Council Framework Decision amending Framework Decision 2002/475/JHA on combating terrorism. SEC (2007) 1424/2.

Commission Staff Working Document accompanying document to the Proposal for a Council Framework Decision on preventing and combating trafficking in human beings, and protecting victims, repealing Framework Decision 2002/629/ JHA. SEC (2009) 358.

Commission Staff Working Document accompanying document to the Proposal for a Directive on the protection of the environment through criminal law. SEC (2007) 160.

Commission Staff Working Paper accompanying document to the Proposal for a Directive of the EP and of the Council providing for sanctions against employers of illegally staying third-country nationals. SEC (2007) 596.

Communication from the Commission to the Council and the European Parliament. Area of Freedom, Security and Justice: Assessment of the Tampere programme and future orientations. COM (2004) 401 final, Brussels, 2 June 2004.

Communication from the Commission to the European Parliament and the Council. Measuring in the EU: Statistics Action Plan 2011-2015. COM (2011) 713 final, Brussels, 18 January 2012.

Communication from the Commission to the European Parliament, the Council and the European Economic and Social Committee. Developing a comprehensive and coherent EU strategy to measure crime and criminal justice: An EU Action Plan 2006-2010. COM (2006) 437 final, Brussels, 7 August 2006.

Communication on the Hague Programme: Ten priorities for the next five years - The Partnership for European renewal in the field of Freedom, Security and Justice. COM (2005) 184 final, Brussels, 10 May 2005.

Decision 1578/2007/EC of the European Parliament and of the Council of 11 December 2007 on the Community Statistical Programme 2008-2012 (Official Journal L344 of 28 December 2007). 
Document de travail de la Commision Annexe à la Proposition de Décision Cadre du Conseil visant le renforcement du cadre pénal pour la répression des atteintes à la propriété intellectuelle [SEC (2005) 848].

European Commission: Impact Assessment Guidelines, 15 June 2005. SEC (2005) 791.

European Commission: Impact Assessment Guidelines, 15 January 2009. SEC (2009) 92.

European Governance. A White Paper. COM (2001) 428 final, Brussels, 27 July 2001.

The Hague Programme: Strengthening Freedom, Security and Justices in the European Union (Official Journal C53 of 3 March 2005).

The Prevention and Control of Organised Crime: A European Union Strategy for the Beginning of the New Millennium (Official Journal C1124 of 3 May 2000).

The Stockholm Programme - An Open and Secure Europe Serving and Protecting Citizens (Official Journal C115 of 4 May 2010).

Regulation (EC) No. 223/2009 of the European Parliament and of the Council of 11 March 2009 on European statistics and repealing Regulation (EC, Euratom) No. 1101/2008 of the European Parliament and of the Council on the transmission of data subject to statistical confidentiality to the Statistical Office of the European Communities, Council Regulation (EC) No. 322/97 on Community Statistics, and Council Decision 89/382/EEC, Euratom establishing a Committee on the Statistical Programmes of the European Communities (Official Journal L87 of 31 March 2009).

Regulation (EC) No. 862/2007 of the European Parliament and of the Council of 11 July 2007 on Community statistics on migration and international protection and repealing Council Regulation (EEC) No. 311/76 on the compilation of statistics on foreign workers (Official Journal L199, 31 July 2007). 